\title{
POLITICS IN THE WESTERN MAYA REGION (III): THE ROYAL AND THE NON-ROYAL ELITE
}

\author{
PÉTER BíRÓ \\ Abteilung für Altamerikanistik, Bonn
}

\begin{abstract}
RESUMEN: En una serie de artículos investigo el uso de varias palabras en las inscripciones mayas de la época Clásica de la Región Occidental que se conectan con la que nosotros llamamos política. Estas palabras expresan ideas y conceptualizaciones que ayudan a entender los matices de las relaciones entre las entidades políticas de las Tierras Bajas Mayas y su organización interna. En este artículo investigo la distribución de los títulos secundarios. Propongo que, en vez de indicar un crecimiento del poder de la élite secundaria, aquellos proporcionan evidencia de la existencia de diferentes géneros inscripcionales que tal vez reflejen procesos históricos diferentes dentro de cada región.
\end{abstract}

Palabras Clave: Maya Clásico, epigrafía, reyes y nobles, competición.

ABSTRACT: In a series of articles I reflect on the use of various expressions which are connected to what we call the political in the inscriptions of the Classic Maya Western Region. These words express ideas and conceptualisations which help to understand the intricate details of the interactions between the political entities and their internal organisations in the Classic Maya Lowlands. In this article I investigate the distribution of the non-royal elite titles. I suggest that they indicate different inscriptional genres instead of being signs of the growing power of the secondary elite. Also, they might be the evidence of different historical processes in each region.

Keywords: Classic Maya, epigraphy, kings and nobles, competition.

RECEPCIÓN: 9 de enero del 2011

ACEPTACIÓN: 5 de noviembre del 2011. 



\title{
POLITICS IN THE WESTERN \\ MAYA REGION (III): \\ THE ROYAL AND THE NON-ROYAL ELITE*
}

\author{
PÉTER BíRÓ \\ Abteilung für Altamerikanistik, Bonn
}

During the Classic Period a bewildering array of titles were used in the inscriptions. With the decipherment of new logograms and syllables, new titles (or new readings of formerly recognised titles) are discovered. Due to this dynamic situation there are various ideas circulating about these titles, about their readings, translations, the functions connected to them and interpretations concerning what their use and appearance attest about political organisation.

Khristaan Villela (1993) based on previous works (Stuart, 1984; Schele and Freidel, 1990: 261-305, 328-334; 380; Schele and Mathews, 1991 [1996]) did a very early and useful treatment of the titles. Nevertheless, most of the titles were not deciphered during this period or were not transcribed correctly which renders Villela's work out of date with current practice. From the second half of the 1990s more special epigraphic work concentrated on titles and they added useful data about time periods, readings, translations, costume, etc. of the holder of these titles (Houston and Stuart, 2001; Jackson and Stuart, 2001; Parmington, 2003; Beliaev, 2004; Zender, 2004).

One particular interpretation, first expressed in the late 1980s by various epigraphers and archaeologists, is the idea that elite persons who did not have the right to rule (non-royal or secondary elite) were competitors to members of the ruling houses of Classic Maya cities (Culbert, 1991 [1996]; Webster, 1999, 2000; Houston and Stuart, 2001). As the number of the secondary elite grew their power increased accordingly and rulers needed to accommodate them by several mechanisms, such as the representation of secondary elite on public monuments, and the mention of them in royal inscriptions. More mention in texts and more frequent representation on monuments thus indicate the growing power

I began to write this paper in 2009 at La Trobe University, Australia. I continue the article at the Institut für Altamerikanistik at Bonn, Germany. In Australia I received funding from a La Trobe University Posgraduate Research Scholarship and also from an International Posgraduate Research Scholarship, while in Germany my stay is financed by the Humboldt Stiftung. I would like to thank to Peter Mathews his help during my stay in Melbourne. I cannot thank enough the kind offer of Nikolai Grube to work in Bonn. My research benefited from ideas of many colleagues such as Dmitri Beliaev, Alexander Safronov, Albert Davletshin, Christian Prager, Elisabeth Wagner, Guido Krempel and Barbara MacLeod. I thank for Doorshysingh Jugessur for reading the manuscript and correcting it with his fine insights. 
of the secondary elite and a decreasing power of the royal houses. I will call this proposition the theory of the proliferation of the non-royal elite.

In my paper I will investigate this proposition based on the epigraphic data from the Western Maya Region whose inscriptions gave the impetus to formulate such a theory. At first I briefly explain my use of the terms royal and non-royal elite then present in detail the most important expressions of the ideas about the proliferation of the non-royal elite. In the second part of the paper I present data from epigraphy and iconography which challenges the theory of the proliferation of the non-royal elite. I will argue that from the inception of monument erection the non-royal elite were mentioned in the inscriptions and were represented on public monuments of the rulers in the Western Maya Region. Texts from other regions indicate that the case of the Western Maya Region is the expression of a regional pattern of inscriptional genre which cannot be extended for the entire Classic Period Maya Lowlands. I will suggest one possible explanation for the development of such an inscriptional genre. The theory of the proliferation of the non-royal elite therefore needs to be re-examined and at best taken with caution in the reconstruction of political and developmental events of the Classic Period.

\section{Royal and Non-Royal Elite}

Classic Maya society was certainly divided into at least two social strata which researchers usually call elite and commoners (Hammond, 1991). However, more precise divisions are attested in archaeology and in epigraphy, but debate is still very much alive about the exact configuration (Chase and Chase, 1992; Inomata and Houston, 2001). The majority of the persons mentioned in Classic Period inscriptions have at least one title which indicates social rank or occupation. Among those titled elite we can differentiate two separate groups. The first one consists of the ruler and his immediate family (mother, father, sons, and daughters), and the second one of a wide range of elite persons who usually has various titles such as aj k'uhun, ti' sak hun, sajal, yajaw k'ahk', yajaw te', lakam, a'nab', etc. I call the first group the royal elite and the second group I call the non-royal or secondary elite.

In archaeology and epigraphy both are well differentiated from the commoners but it is harder to make internal group divisions (Jackson, 2005). Status markers such as clothing, insignia, sculpture and architecture are all helpful in recognising the elite. One of the main markers of elite status was the ability to commission architectural sculpture and especialy monuments with texts and iconographic representations. When archaeologists and epigraphers theorise about the competition among elite members usually they think about status rivalry among titled individuals who have the capacity to explicitly represent themselves on monuments. 


\section{Previous Theories of Competition between Royal and Non-Royal Elite}

In a School of American Research Advanced Seminar held in 1986 epigraphy and archaeology was combined in a synthethic work which was published in 1991 (Culbert, 1991 [1996]). The resulting book is the first testament of the idea which proposes that from the middle of the $8^{\text {th }}$ century AD the non-royal elite gained the privilege to be represented with the supreme ruler on "public monuments" and that admission clearly represented the lessening of royal power. As Linda Schele put it in a chapter dealing with the Western Maya Region:

...cahals had the right from the beginning of the Classic period to commission and display monuments recording their own history... at their home sites or within their own residential compounds. By...751, at Yaxchilan and Piedras Negras cahals are given billing with the high kings on public monuments commissioned by the kings...this represents a change in political adaption responding to growing pressures on central authority from ecological, population, and social pressures. (Schele, 1991 [1996: 87])

William Fash and David Stuart added that:

The strong dependence on the charisma and actions of the Classic Maya ruler, and the relatively underdeveloped nature of hierarchical institutions divorced from kinship lines, meant that it was difficult to accommodate the perceived needs and rival claims of the competing non-kingly factions...The innovative approaches to this problem devised and implemented by the $16^{\text {th }}$ Copan ruler indicate a willingness (arguably borne of need) to engage in power sharing. Unfortunately...[that] culminated in the demise of dynastic power at Copan. (Fash and Stuart, 1991 [1996]: 178)

Other scholars agreed with them that the rulers, heads in a formerly centralised realm, tried to share their power which led to decentralisation and ultimately to the demise and collapse of the Classic Period political system.

A later addition to the power sharing hypothesis claims that from the beginning of the Classic Period (AD 250), in parallel to the demographic growth of the general population, the number of elites grew exponentially. Because of underdeveloped hierarchies and lack of available ranks and titles, there was a growing factional competition among non-royal and royal groups. This competition first led to the sharing of power by rulers and later to the demise of the whole political system (Houston, 1993). The often-cited models derive from Polynesian societies and they run under the name of status-rivalry competition (Webster, 1999, 2000, 2004; Houston and Stuart, 2001). Stephen Houston and David Stuart summed up this process based on epigraphic data as the following:

With scant exception, all references to woman date to the Late Classic period (ca. A.D. 600 to 800); all Mesoamerican references to sajal date to the same time with 
a clear unimodal curve, and the same holds true for other nonregnal titles. There are several ways to interpret these data: (1) the pattern is spurious, reflecting little more than a vastly increased sample of monuments from the Late Classic; (2) the pattern is real, reflecting a shift in rhetoric...; (3) the pattern is real and records the actual institution of new kinds of non-regnal nobility. We believe that numbers 2 and 3 are closer to the mark...That is, by the Late Classic period nonregnal elites had become obtrusive both numerically and rhetorically... (Houston and Stuart, 2001: 73)

Although these three quotes do not exhaust entirely the variety of theoretical tenets, and especially their details, they represent well in general the underpinnings of the ideas which I termed as hypothesis of the proliferation of the nonroyal elite.

\section{The Proliferation of the Non-Royal Elite: Critical Observations}

Although the date is not explicit in the quote from William Fash and David Stuart, the "sharing of power" clearly occurred in the second half of the $8^{\text {th }}$ century as the $16^{\text {th }}$ ruler of Copan, Yax Pasaj Chan Yopaat ruled from 768 till the 820 's. ${ }^{1}$ There are at least two problems with these assertions. First it is not clear what counts as a public monument (these are usually the monuments which fit the argument of the researcher), and second the time frame needs corrections. By the criteria of Linda Schele, monuments in the site of the non-royal elite, or in the residential compound of non-royal elite within the centre of the overlord, do not indicate power sharing. This rules out all the inscriptions of the non-royal elites in Copan, which are to be found in thrones or benches within their respective residential compounds (for example $9 \mathrm{~N}-82$ and $9 \mathrm{M}-146$ ).

What Linda Schele thought as "public monuments" were the freestanding stelae on the central plazas of royal centres, especially the ones near the supposed royal compound. Even if an epigrapher sticks to that apparently narrow definition, the process of planting a subordinate's monument on a plaza was a much earlier phenomenon than Linda Schele indicated in her article (pre-750). In the Western Maya Region this is attested from the beginning of the Late Classic Period.

In Tonina, one aj k'uhun celebrated his accession and a period ending in 615 on his own stela, which was the first of various monuments produced by nonroyal elites in "public places", in royal centres (figure 1). Also their importance on the monuments of rulers can be ascertained from at least 633 onward when the accessions of two non-royal elite nobles are recorded (an aj k'uhun and a nu'n) on a free-standing monument. In Tonina such representational and discursive

${ }^{1}$ Later epigraphic decipherments clarified the identities of the so-called co-rulers of Yax Pasaj Chan Yopat as different gods such as Yax Kamlay or Nun Ujol B'ak. 


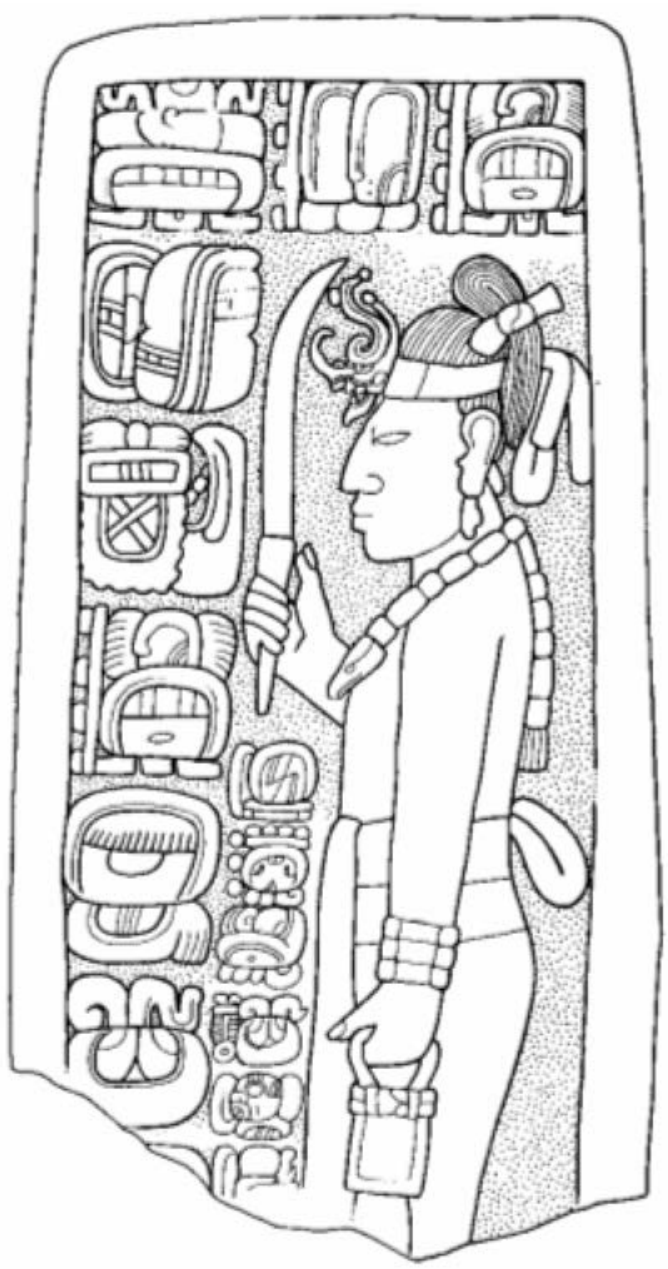

Figure 1. Tonina Monument 183. Drawing by Simon Martin

practices continued into the $7^{\text {th }}, 8^{\text {th }}$ and $9^{\text {th }}$ centuries with public monuments commissioned by non-royal elites, and with public monuments erected by rulers in mentioning the non-royal elite (M.8-682, M.140-697, M.122-711, M.136-716, M.p.31-717, M.110-726, M.p.17/44-787).

The situation in Piedras Negras, one of the two examples cited by Schele (1991 [1996]: 87), was not at all different. The list begins with Stela 26 dated to AD 628 where two captives are represented, one is an aj k'uhun. The next king then represented dignitaries of his father in a public monument (Panel 4-658), and that tradition continued showing important subordinates interacting with 
the ruler (Panel 2-667, Panel 7-678, Panel 15-706, Panel 3-782). Also kings represented or mentioned their ajaw, sajal, aj k'uhun or ti' sak hun on various stelae from the $7^{\text {th }}$ century on (Stela 6-687, Stela 2-697, Stela 5-716, Stela 11-731, Stela 40-746, Stela 16-766, Stela 12-795).

In Yaxchilan-the example of Schele-the situation is much more complex and difficult to analyse because of the substantial discontinuity in the inscriptions. There are two serious gaps: one between 537 and 613, and another between 613 and 689. Apart from these gaps, it is now known that all remaining monuments dated before 688 were relocated or sometimes recarved. There is evidence that these gaps are due to conquest and the lost of independence, although archaeological work is lacking into the earlier layers of the site (Mathews, 1988 [1997]; Grube, 1999; Martin and Grube, 2000). However, the representation of secondary nobles in the public monuments of Itzamnaj B'ahlam III and its followers is a normal political process, and not an exception, in light of the examples of Tonina and Piedras Negras, and it is equally possible that the rulers of Yaxchilan employed a region wide inscriptional practice.

From the above remarks I think it is too early to conclude that there was any significant change in the representation of non-royal elite on royal public monuments during the $8^{\text {th }}$ century, and in turn, this indicates a pressure on the royal line, or a kind of power-sharing.

On the central lowlands, although most of the titles are attested, they are rarely mentioned on public monuments (only as captives, save one very early ti' sak hun on Tikal Stela 8, and another ti' sak hun and aj k'uhun in the otherwise subordinate sites of La Corona). On the other hand, they are mentioned on polychrome ceramics and other non-public inscriptions like bones and shells. The real difference is therefore between representational and discursive strategies of the Northeast Peten and the Western Maya Region, which begin certainly earlier than the middle of the $8^{\text {th }}$ century which challenges ideas of decentralisation and loss of power by the rulers, at least at that specific period.

Houston and Stuart (2001: 73) emphasised that the secondary elite became more obtrusive from the beginning of the Late Classic Period or from 600, although Schele (1991 [1996: 87]) rather stated that secondary nobles had the right to commission their own monuments from the beginning of the Classic Period.

Problems with the assertions of Houston and Stuart are manifold. First, the assertion that the use of sajal (and aj k'uhun titles) reflects the use of other nonroyal elite titles is not just conceptually, but empirically erroneous. It is especially mistaken when it is examined in light of Western Maya Region inscriptions (see later).

Also, it is necessary to make a difference between contemporary and retrospective accounts embedded in later narratives. The first contemporary inscribed monument from the Western Maya Region is from 495 and was commissioned by an a'nab' (Houston Panel; figure 2). Another is from the beginning of the $6^{\text {th }}$ 


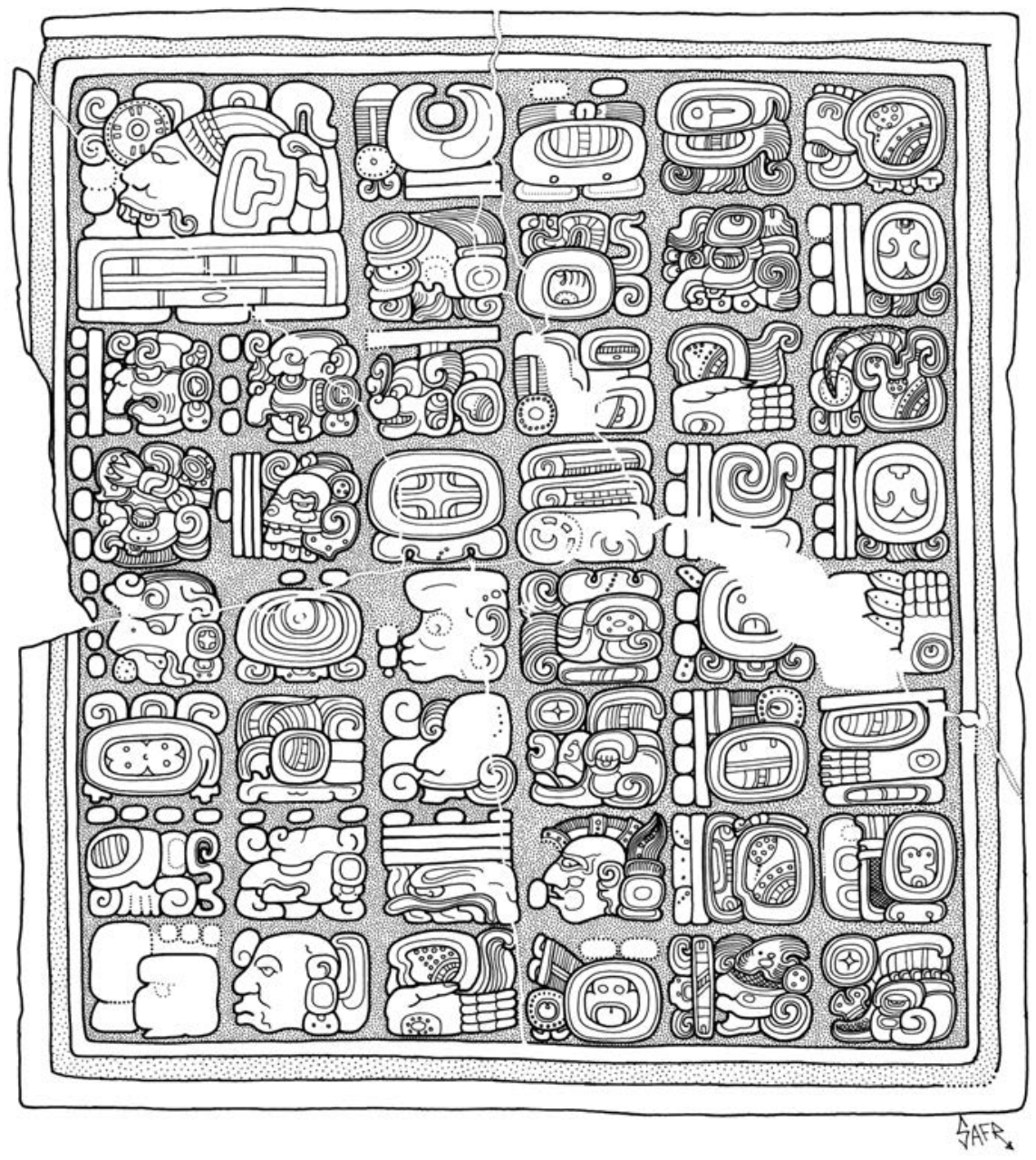

Figure 2. The Houston Panel.

Drawing by Alexander Safronov (Wayeb Drawing Archive)

century by the same a'nab' (Po Panel; figure 3). While the first one is entirely glyphic, on the latter one there is no difference between the representation of the king and his dignitary. From the same region, there are very early monuments from the $6^{\text {th }}$ century which were commissioned by yajaw te', representing themselves as rulers.

The first royal inscriptions are from 514 in Tonina, Piedras Negras and Yaxchilan and from 649 in Palenque. That is, both royal and non-royal elite commissioned their inscriptions from the $6^{\text {th }}$ century, at least 100 years earlier than 


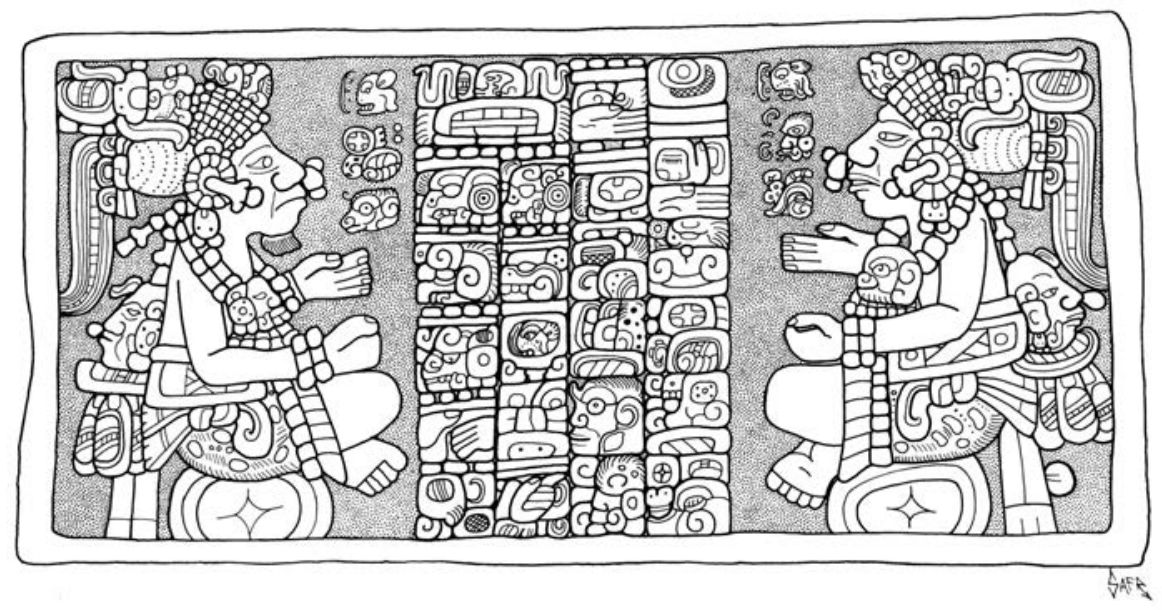

Figure 3. The Po Panel.

Drawing by Alexander Safronov (WAYEB Drawing Archive)

suggested by Houston and Stuart (2001). Nevertheless, just as there are not too many royal monuments from the Early Classic Period from the Western Maya region, there are no monuments of secondary elite persons, which is probably due to the lack of excavation into the earlier layers of sites.

The origin of dynasties is only known from retrospective texts from all sites, and they (the texts) indicate that most of the dynasties were founded in the late $4^{\text {th }}$ and early $5^{\text {th }}$ centuries in the Western Maya Region. There are indications that the dynastic founders came from outside of the region, more probably from the Northeast Peten. The retrospective texts are coming from the $7^{\text {th }}-8^{\text {th }}$ centuries, save an early set of lintels from Yaxchilan from the first half of the $6^{\text {th }}$ century.

As a matter of fact, the same kind of retrospective inscriptions about the founding of non-royal elite families are known from the first half of the $6^{\text {th }}$ century (a yajaw te'-Ojo de Agua Stela 1; figure 4), and from the $8^{\text {th }}$ and $9^{\text {th }}$ centuries (sajal and ajaw 'headband bird'-The Randall Stela and the Palenque Kan Tok Tablet, respectively; figures 5 and 6). They both record an early $5^{\text {th }}$ century foundation of the respective families. Although this date is later than the foundation of royal houses but earlier than the first contemporary mention of the non-royal elite.

This indicates that non-royal elite families used the same narrative device as the royal houses in roughly the same epoch to signal high status, and though I do not deny the status-competition/rivalry, the whole political system remained "stable" (without imminent collapse) during four centuries.

Though it is reasonable to assume that the number of the non-royal elite grew with the growth of the population of the Maya Lowlands (Culbert and 


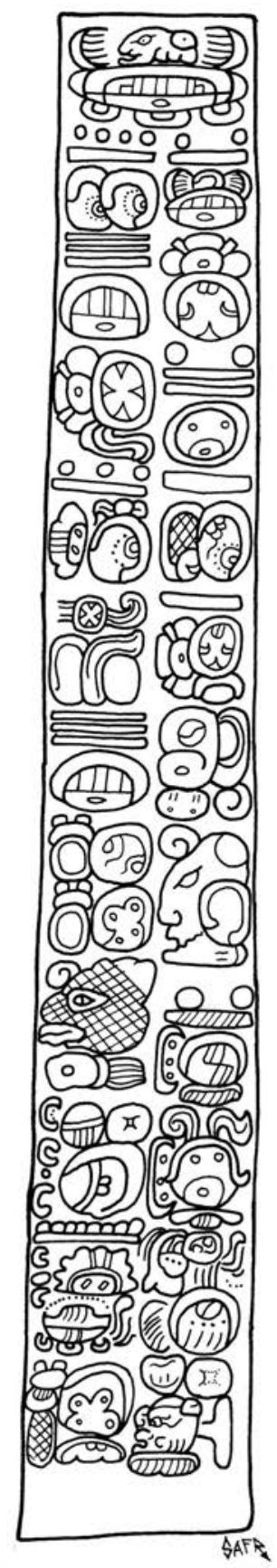

Figure 4. Ojo de Agua Stela 1.

Drawing by Alexander Safronov (WAYEB Drawing Archive) 


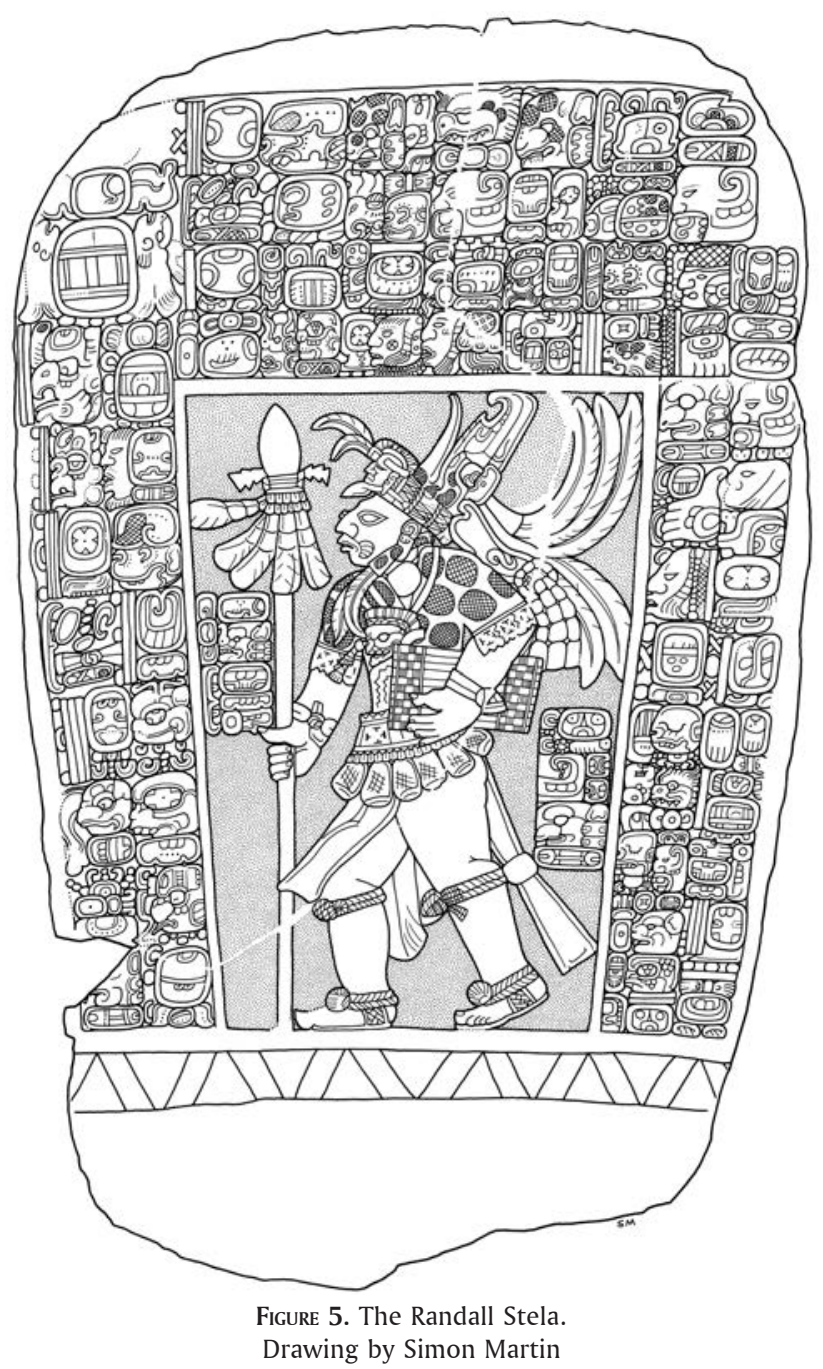

Rice, 1990), it is much more difficult to decide whether their number relative to the royal houses and the commoner population was "obtrusive...numerically". Houston and Stuart (2001: 75) present two figures which show that the temporal distribution of sajal and aj k'uhun titles were parallel to the growth of the population. That figure is clearly thought provoking, however, in case of the yajaw te' titles the figures would be different as these are concentrating in the $6^{\text {th }}$ centuries, and they are rarely mentioned in the $8^{\text {th }}$ century.

Marc Zender (2004: 387-393) supplemented the data of Houston and Stuart with the adding of the temporal distribution of yajaw k'ahk' and ti' sak hun title 


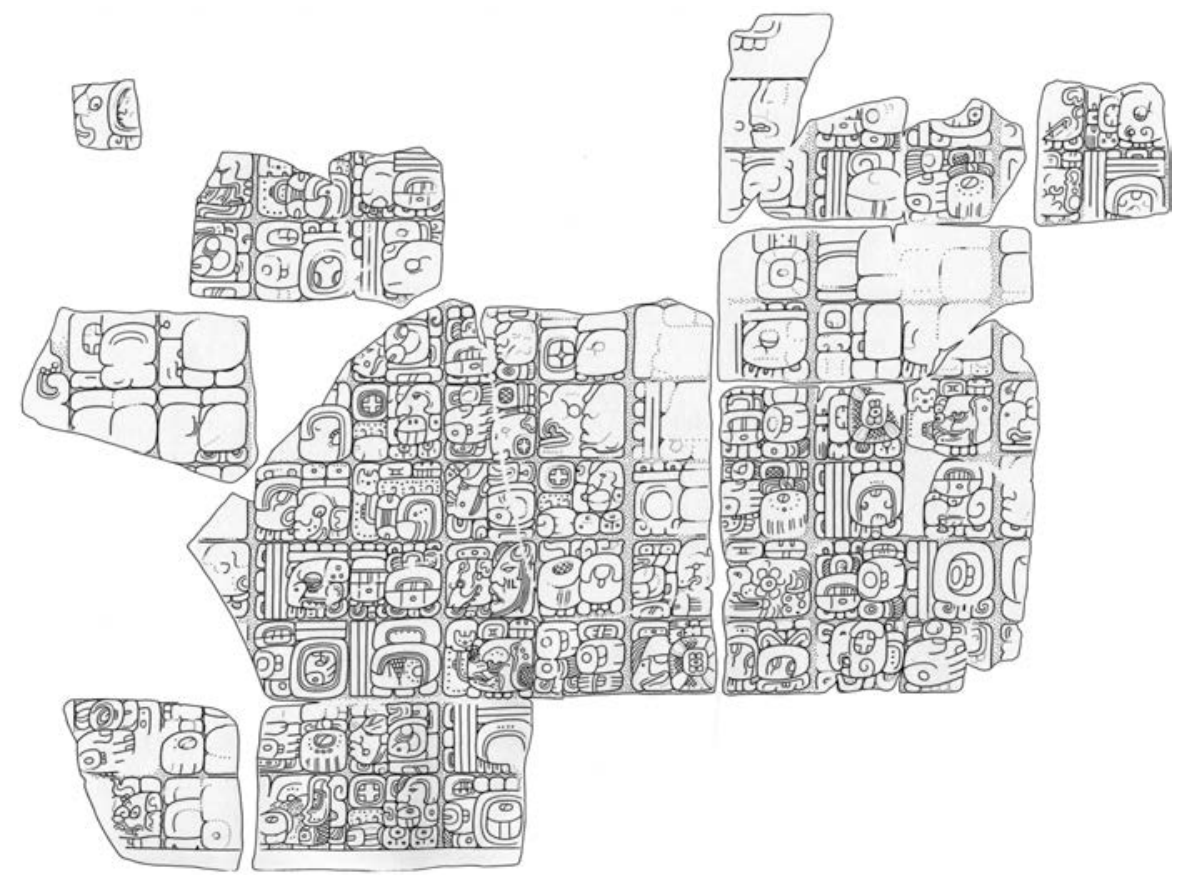

Figure 6. The K'an Tok Tablet

(Drawing by Peter Mathews-Mesoweb Archive)

holders (and some new mentions of sajal and aj k'uhun) and compared this to the temporal distribution of dated events from Classic Period monuments. His conclusions (Zender, 2004: 390-391), however, are contrary to the interpretation of Houston and Stuart (2001):

conventions affecting depictions and citations of Maya priests, has skewed the apparent distribution of non-regnal titles significantly...Obviously, the presence of high-status non-regnal elites and religious specialists in Middle Classic Maya society of the $5^{\text {th }}$ and $6^{\text {th }}$ centuries A.D. must cast at least some doubt on the "nobles' revolt" "popol nah" and other nascent heterarchical models predicated of the advent of such individuals only in the mid to late $8^{\text {th }}$ century A.D. (Zender, 2004: 390-391)

In her PhD dissertation Sarah Jackson (2005) made an exhaustive study of the geographic and diachronic distribution of five titles (sajal, aj k'uhun, ti' sak hun, yajaw k'ahk' and headband bird titles). Her geographical division is different from mine, however her Usumacinta River, Larger Usumacinta River and Tabasco regions correspond well to the Western Maya Region. According to her analysis there is a diachronic distribution of titles ranging from AD 435 to AD 881 (with some retrospective records). Also, she notes that the only major difference in 
media representation between the royal and non-royal elite is the minimal access to own a stela by the latter (only 6\%). The non-royal elite had a high number of inscriptions on doorway architecture (32\%) and panels/tablets $(26 \%)$ and on portable objects $(20 \%)$.

What is missing from this analysis is the comparison of regional preference for different types of monuments, that is whether the pattern of non-royal monument type ownership reflects an imitation of royal habits or not (in Palenque there is no stelae but there is a high number of panels/tablets commissioned both by the royal and non-royal elite).

The distribution of titles indicates a marked regionalism. 73\% of the mention of the five titles come from the Western Maya Region which led Jackson (2005: 150) to suggest the possibility of a political sphere of interaction with which I agree. The greatest difference is between the Northeast Peten and the Western Maya Region because of the number of inscriptions present (high number of inscriptions in both regions): only $9 \%$ of the records of non-royal elite come from the Northeast Peten, and most of them are on portable objects. These quantitative data concur with a qualitative assessment that the Northeast Peten Region do not have a significant amount of monuments by non-royal elite individuals.

Although the growing importance of the non-royal elites are well-attested elsewhere archaeologically (in Copan non-royal elite masonry structures appear late, around 650; see Webster, 2004: 60), their existence is much earlier in the Western Maya Region, documented in Palenque Group XVI and Group IV built around 450-550 that remained occupied by elite groups until the end of the Classic Period (the first had inscriptions from the $7^{\text {th }}$ and $8^{\text {th }}$ centuries; see Bernal, n.d.a).

\section{Final Observations}

Both the language of the inscriptions in the Western Maya region and the concepts of political vocabulary do not differ substantially from that of the Northeast Peten. A salient feature of the textual material of the region is the unique emphasis put on the representation of non-royal secondary elite individuals. Contrary to the views held by various epigraphers, I think that this was a political strategy implemented from the beginning of dynastic rule, which remained in use during the history of the region. The Western Maya Region ruler's acceptance to represent their non-royal elite companions leads me to suggest the existence of a different way of organising political ties. Families of sajal, a'nab', aj k'uhun and ti'

sak hun were influential enough to be mentioned in royal inscriptions from the late $5^{\text {th }}$ century and strangely the first contemporary inscriptions from the region are two short texts dedicated by an a'nab' with a formal and narrative style which remained constant through the following centuries.

Although in other regions the secondary elite rarely appears on inscriptions which are incorporated into buildings or free standing monuments, scholars 
stated that from the $7^{\text {th }}$ century onward there is a sudden surge in their appearance in royal texts. This is partially true in the polities of the Southeastern Maya region of Copan and also in the Puuc where there is no mention of them before the very late $7^{\text {th }}$ century. In the Northeast Peten, however, their mention mainly comes from painted polychrome ceramics. This alone indicates differential artistic styles and considerations but it is very difficult to decide what underlying political issues this pattern reflects.

Elsewhere (Bíró, 2009) I offered one possible explanation which I call the "politics of incorporation". This hypothesis is directly connected to the origin of dynastic rule in the Usumacinta area. There are some data which would indicate that several dynasties of the Usumacinta region might have come from sites of the Peten (Houston et al., 2003; David Stuart personal communication, 2005; Bíró, 2009). The integration of the local population by the new rulers would have been a necessary prerequisite to the founding of the polities. This in turn might have led to a different relationship between the (initially foreign) rulers and the pre-existing local elite. As such, the situation of the founding of polities in the western region might have been similar to the founding of Copan and elsewhere (Martin and Grube, 2000: 193).

The development of subordinate offices and the elevation of local highly ranked persons into those offices in a hierarchy whose top position was filled by a supreme ruler (k'uhul ajaw) might have been a successful political strategy in the consolidation of the new western polities. Preliminary data seem to indicate that the late $5^{\text {th }}$ and early $6^{\text {th }}$ centuries were crucial in the development of the important political centres in the region. Some archaeological evidence supports this view.

Rather than seeing competition between rulers and nobles, a strategic alliance between an initially intrusive elite population and local elite is a possible scenario where the creation or donation of titles was mutually beneficial.

The evidence for what I call the proliferation of the non-royal elite is tenuous and it is not attested in the inscriptions. Non-elite persons were mentioned in different contexts in different regions and on different media. They commissioned their own inscriptions and their representations on royal monuments date from the $5^{\text {th }}$ century in the Western Maya Region but they lack such media space in the Northeast Peten. In turn they occupied an important place in polychrome ceramics where their representations abound and certainly commissioned some of those vessels and plates.

As a final thought, the epigraphic and archaeological records of the Maya Lowlands are more varied to simply conclude that the competition of the nonroyal elite with the regnal dynasties played a significant role in the collapse. Evidence is on warfare among the competing supreme rulers and the disruption it caused in the lives of the general population rather than on conflicts among the non-royal and royal elites (only one record in texts from a period of AD 378 to 909 ). 


\section{REFERENCES}

Beliaev, Dmitri D.

2004 “Wayaab’ Title in Maya Hieroglyphic Inscriptions: On the Problem of Religious Specialization in Classic Maya Society”, Continuity and Change: Maya Religious Practices and Temporal Perspective: $5^{\text {th }}$ European Maya Conference, University of Bonn, December 2000, Acta Mesoamericana, Vol. 14., Daniel Graña Behrens et al. (eds.). Markt Schwaben [Germany]: Verlag Anton Saurwein, 121-130;

Bernal Romero, Guillermo

n.d.a "El Tablero de K’an Tok. Reconstrucción, análisis, epigráfico e implicaciones historiográficas de una inscripción glífica maya del Grupo XVI, Palenque, Chiapas", tesis de maestría en Estudios Mesoamericanos. Mexico: Universidad Nacional Autónoma de México, Facultad de Filosofía y Letras, Instituto de Investigaciones Filológicas.

Bíró, Péter

2009 "Classic Maya (AD 300-900) Political History and Political Organisation in the Western Maya Region: An Inscriptional Analysis”, PhD Dissertation. Melbourne: La Trobe University, Department of Archaeology.

Chase, Diane and Arlen F. Chase (eds.)

1992 Mesoamerican Elites: An Archaeological Assessment. Norman: University of Oklahoma Press.

$\mathrm{CMHI}$

Corpus of Maya Hieroglyphic Inscriptions 1977-, Volumes 1-9, Cambridge: Harvard University, Peabody Museum of Archaeology and Ethnology.

Culbert, Patrick (ed.)

1991 Classic Maya Political History: Hieroglyphic and Archaeological Evidence. Cam-

[1996] bridge: Cambridge University Press.

Culbert, Patrick T. and Don S. Rice (eds.)

1990 Precolumbian Population History in the Maya Lowlands. Albuquerque: University of New Mexico Press.

Fash, William and David Stuart

1991 [1996] "Dynastic History and Cultural Evolution at Copan Honduras", Classic Maya Political History: Hieroglyphic and Archaeological Evidence, Patrick T. Culbert (ed.). Cambridge: Cambridge University Press, 147-179.

Grube, Nikolai

1999 "Observations on the Late Classic Interregnum of Yaxchilan", The Archaeology of Mesoamerica: Mexican and European Perspectives, Warwick Bray and Linda Manzanilla (eds.). London: British Museum Press, 116-127. 
Hammond, Normand

1991 "Inside the Black Box: Defining Maya Polity", Classic Maya Political History: Hieroglyphic and Archaeological Evidence, Patrick Culbert (ed.) Cambridge: Cambridge University Press, 253-284.

Houston, Stephen D.

1993 Hieroglyphs and History at Dos Pilas: Dynastic Politics of the Classic Maya. Austin: University of Texas Press.

Houston, Stephen D., Héctor Escobedo, Mark Child, Charles Golden and René Muñoz 2003 "Moral Community and Settlement Transformation among the Classic Maya: Evidence from Piedras Negras, Guatemala", The Social Construction of Ancient Cities, Monica L. Smith (ed.). Washington, DC: Smithsonian Institution Press, 65-93.

Houston, Stephen D. and David Stuart

2001 "Peopling the Classic Maya Court", Royal Courts of the Ancient Maya, volume 1, Takeshi Inomata and Stephen D. Houston (eds.). Boulder: Westview Press, 54-83.

Inomata, Takeshi and Stephen D. Houston (eds.)

2001 Royal Courts of the Ancient Maya. Boulder [United States]: Westview Press.

Jackson, Sarah E.

2005 "Deciphering Classic Maya Political Hierarchy: Epigraphic, Archaeological, and Ethnohistoric Perspectives on the Courtly Elite", PhD Dissertation. Boston: Harvard University Press, Department of Anthropology.

Jackson, Sarah E. and David Stuart

2001 “The Aj K'uhun Title: Deciphering a Classic Maya Term of Rank”, Ancient Mesoamerica, 12: 217-228. Cambridge: Cambridge University Press.

Martin, Simon and Nikolai Grube

$2000 \quad$ Chronicle of Maya King and Queens: Deciphering of the Ancient Dynasties of the Ancient Maya. London: Thames and Hudson.

Mathews, Peter

1988 La Escultura de Yaxchilan. Mexico: Instituto Nacional de Antropología e His[1997] toria.

Mesoweb Archive. Palenque Resources. Monuments \& Inscriptions

$<$ http://www.mesoweb.com/palenque/monuments/kantok/index.html > [Retrieved November $9^{\text {th }}, 2012$.]

Parmington, Alexander

2003 "Classic Maya Status and the Subsidiary "Office" of Sajal: A comparative study of status as represented in costume and composition in the iconography of monuments", Mexicon, 25 (2): 46-53. Mark Schwaben [Germany]: Verlag Anton Sauerwein. 
Schele, Linda

1991 "An Epigraphic History of the Western Maya Region”, Classic Maya Political

[1996] History: Epigraphic and Archaeological Evidence, Patrick T. Culbert (ed.). Cambridge: Cambridge University Press, 72-101.

Schele, Linda and David Freidel

1990 A Forest of Kings: The Untold Story of the Ancient Maya. New York: William Morrow.

Schele, Linda and Peter Mathews

1991 "Royal Visits and Intersite Relationships among the Classic Maya", Classic

[1996] Maya Political History: Epigraphic and Archaeological Evidence, Patrick T. Culbert (ed.). Cambridge: Cambridge University Press, 226-252.

Stuart, David

1984 "New Epigraphic Evidence of Political Organization in the Classic Maya Lowlands". Unpublished manuscript.

Villela, Khristaan D.

1993 "Classic Maya Secondary Tier: Power and Prestige in Three Polities", MA Thesis. Austin: University of Texas, Department of Art History.

Wayeb Drawing Archive

<http://www.wayeb.org/resourceslinks/wayeb_drawings.php > [Retrieved November $9^{\text {th }}, 2012$.]

Webster, David

1999 "Warfare and Status Rivalry: Lowland Maya and Polynesian Comparisons", Archaic States, Gary M. Feinman and Joyce Marcus (eds.). Santa Fe: School of American Research Press, 311-351.

2000 "Not so Peaceful Civilization: a Review of Maya war", Journal of World Prehistory, 14 (1): 65-119. New York: Kluwer Academic Press

2004 "Political Ecology, Political Economy, and the Culture History of Resource Management at Copán”, Copan: The History of an Ancient Maya Kingdom, E. Wyllys Andrews and William L. Fash (eds.). Santa Fe: School of American Research Press, 33-72.

Zender, Marc

2004 "A Study of Classic Maya Priesthood", PhD Thesis. Calgary: University of Calgary, Department of Archaeology. 